\title{
Immigrant Memoirs in the Service of Americanization: Between "the Melting Pot" and Cultural Pluralism
}

Anita Jarczok

\section{(2) OpenEdition}

\section{Journals}

Electronic version

URL: https://journals.openedition.org/ejas/17128

DOI: 10.4000/ejas.17128

ISSN: 1991-9336

Publisher

European Association for American Studies

Electronic reference

Anita Jarczok, "Immigrant Memoirs in the Service of Americanization: Between "the Melting Pot" and Cultural Pluralism", European journal of American studies [Online], 16-2 | 2021, Online since 14 July 2021, connection on 17 October 2022. URL: http://journals.openedition.org/ejas/17128 ; DOI: https:// doi.org/10.4000/ejas. 17128

This text was automatically generated on 17 October 2022.

\section{(c) (i) (9)}

Creative Commons - Attribution-NonCommercial 4.0 International - CC BY-NC 4.0 https://creativecommons.org/licenses/by-nc/4.0/ 


\title{
Immigrant Memoirs in the Service of Americanization: Between "the Melting Pot" and Cultural Pluralism
}

\author{
Anita Jarczok
}

1 The period of American history between 1820 and 1920 is often called "the century of immigration" (Daniels 119). The number of immigrants steadily grew with each decade, and "the heaviest ten-year period of all time" was between 1905 and 1914, when 10.1 million people arrived in the United States (Daniels 409). As the result of the growing numbers of immigrants and rapidly changing ethnicity patterns of the American population (with fewer immigrants coming from northern and western Europe, and more arriving from its southern and eastern parts), the immigration question was widely debated at the beginning of the twentieth century. Numerous publications, including press articles, academic works, autobiographical narratives, and fictional texts, discussed the real-life problems of immigrants and the possible impact of increased immigration on American society. These texts usually defended one of the three most popular positions at that time, which can be said to be represented by assimilationists, pluralists, and restrictionists. ${ }^{1}$ The first group put forward the idea of an American nation as a melting pot $^{2}$ and insisted that immigrants should blend into their new environment. As Linda Brown explains, "Many pro-immigration texts of this time proposed that, if immigrants could become culturally assimilated, they posed little threat to 'American' society" (Brown 24). Pluralists, as Cristina Stanciu puts it, "argued for Americanization education as a process of cultural exchange rather than coercion," while restrictionists, inspired by "the rise of scientific racism," were convinced that "new immigrants were destroying the national racial stock" and therefore should not be admitted to the country (Stanciu 15,16).

Immigrants themselves also took an active part in that national debate, trying to justify their presence in the United States and to convince Americans that they had something of value to contribute to society. Many of them did so, at least initially, in the pages of their personal memoirs. ${ }^{3}$ This genre had many attractions. Firstly, it was more 
accessible to immigrants, as memoirs were, arguably, easier to compose and publish than, for instance, press articles, which required flawless English and usually an author with a well-established reputation, or fictional works, which demanded more creativity, imagination, and literary ingenuity. ${ }^{4}$ It was not, however, the lack of the burden of literariness that made memoirs so attractive, both for their authors and publishers. The huge influx of immigrants triggered the increased interest of various audiences (social activists, educators, and the newcomers themselves) in life narratives authored by immigrants, which made these texts desirable in the marketplace and resulted in the rapid development of this relatively new literary genre. ${ }^{5}$

Secondly, the narrative framework of the memoir made immigrants' arguments seem less dogmatic and threatening by wrapping them in an appealing and often exotic lifestory. Despite their narrative packaging, these arguments were an important contribution to the immigrant question that was widely debated at the beginning of the twentieth century. According to Boelhower,

The shift ... that was taking place in American culture in the period between 1880 and 1910 had found in ethnic autobiography its corresponding new text-type, which proved to be not only the most suitable vehicle for presenting new and exquisitely modern versions of the American self, but also a lens for interpreting the complex structural tensions that would lead to the closing of the golden doors in 1924. ("The Making of Ethnic Autobiography," 139)

The primary goal of the present study is to analyze selected immigrant memoirs ${ }^{6}$ in order to demonstrate that their authors represented either assimilationist or pluralist views, and not infrequently switched between the two, in order to refute nativist and restrictionist arguments, protect immigrant communities, and contribute to the creation of a unified American nation. The secondary aim is to show that not every memoir written by an immigrant was preoccupied with immigrant dilemmas, and, consequently, to suggest a way of classifying various immigrant life narratives.

While this is not the first study to analyze immigrant memoirs from the beginning of the twentieth century, nor is it the first time that these memoirs have been examined from the perspective of their contribution to the assimilation process, the present study differs from previous ones in terms of the number of immigrant autobiographies that it tries to categorize, and the perspective it assumes. Although some critics argue that it is impossible to classify these narratives, and indeed it is a daunting task, such attempts should not be abandoned, especially because there is a certain division which can prove fruitful and can help us better understand the substantial body of texts authored by European migrants at the beginning of the twentieth century.

One critic who examined immigrant memoirs in terms of assimilation is Richard Tuerk. The main argument of his article "At Home in the Land of Columbus: Americanization in European-American Immigrant Autobiography" is that immigrant autobiographies fall largely into two categories, which are determined by how their authors conceive of their selfhood. He demonstrates his claim in reference to four quite popular memoirs written by Louis Adamic (1932), Mary Antin (1912), Jacob Riis (1901), and M. E. Ravage (1917). According to Tuerk,

Riis and Adamic see themselves as basically unchanged by their American experiences. Each sees his Old World self as an embryonic version of his New World self, and each describes his progression as an evolution proceeding along orderly lines. On the other hand, both Antin and Ravage see almost nothing in their old World selves that indicates what their New World selves will be. (135) 
7 He says that the reasons behind these two different conceptions of self are not clear, mentioning only Antin's and Ravage's Eastern European Jewish background as a possible explanation. Tuerk suggests that as Jews Antin and Ravage experienced discrimination that made them anxious to leave and less nostalgic after they arrived (Tuerk, 136). My own analysis of these two authors reveals significant differences between their attitudes towards assimilation.

8 The first attempt to classify immigrant narratives was arguably undertaken by William Boelhower in his now classic study Immigrant Autobiography in the United States: Four Versions of the Italian Self (1982). ${ }^{7}$ Boelhower distinguishes four different attitudes towards the dominant culture, which he sees exemplified in four Italian autobiographies:

1) "a confirmation of the codes of the dominant culture" - Constantine Panunzio's

The Soul of the Immigrant (1922) [which is also discussed in this essay].

2) "a variation of these codes, in which case the dominant culture is respected but some of its untested possibilities are tried" - Pascal d'Angelo's Son of Italy (1924)

3) "a negotiation of the dominant codes" - Emanuel Carnevali's The Autobiography of Emanuel Carnevali, which was compiled and published by Kay Boyle in 1967.

4) "a substitution of the dominant culture with a counter-cultural alternative" Jerre Mangione's Mount Allegro (1942). Mangione was born to Italian parents in the United States ${ }^{8}$ (20, emphasis original).

Although Boelhower examines texts authored only by writers of Italian origin, he insists that "other ethnic groups ... could have been used to present the same range" (20). Taking a structuralist approach to narrative form, he is convinced that " $[t]$ here is a level at which all immigrant autobiographies tell a single story, project a network of paradigmatic relations, and reveal a homogenous cognitive system" (30; emphasis added), and believes that individual autobiographies are simply "transformations of a single macrotext" (31). This macrotext consists of "three fabula moments of anticipation, contact, and contrast: Old World reality vs. New World ideal, New-World ideal vs. New-World reality, and Old-World reality vs. New World-reality" (40).

The sweeping claim that all immigrant autobiographies share an underlying macrotext is criticized by Sau-ling Cynthia Wong, who suggests that Chinese immigrant autobiographies show that Boelhower's model does not apply to all immigrant life narratives. In these autobiographies, the anticipation moment is non-existent, or a major part of a text is devoted to the immigrant's life in China prior to arrival in America (153-4). She therefore concludes that Boelhower's model is Eurocentric and fits a certain group of writers - writers whose origins can be traced to Judeo-Christian roots and who came to the United States at the turn of the twentieth century (159). This is exactly the group of authors that is of interest to this essay, but it is not as homogenous as it may seem. There are considerable differences between life narratives authored by European immigrants between 1900 and 1930, and this study will suggest a way of thinking about these texts, showing that immigrant status alone does not determine the content of these memoirs. Despite of the fact that all of them were written by immigrants, some are only remotely, if it all, interested in the experience of migration, let alone the Americanization process, which rekindles the old question: which texts should be classified as immigrant autobiographies? A closer look at the narratives authored by various European immigrants in this period will help us systematize our knowledge of these texts, to show that not all of them can be classified as memoirs about Americanization - a distinction made by Wong - and to see how 
those life narratives that do have the Americanization process at heart reflect mainstream perspectives on cultural adaptation.

11 Like Boelhower's study, this essay will concentrate on European immigrants, but unlike his study, it will not focus on any particular ethnic community. It will not be the aim of this essay to test Boelhower's assumption that his proposed model can be applied to other nations. Instead, another way of grouping European immigrant memoirs from the early twentieth century will be suggested. While Boelhower is mainly interested in the ways the author-protagonists negotiate the cultural patterns of the dominant culture in an attempt to create the new, or validate the old, self, this essay singles out one group of immigrant memoirs for thorough examination and considers these narratives against the backdrop of debates that dominated political and cultural discourse on immigration at the beginning of the twentieth century in the United States. A close reading of these texts from such a perspective reveals that they can be divided into two main camps: those supporting assimilation and those promoting cultural pluralism.

12 There is a reason to focus on European immigrants as until the 1960s they constituted the most numerous immigrant group. Their ethnicity, however, was changing. In general, the immigration from northwestern Europe dropped from 95 percent between 1820 and 1860 to 41 percent between 1900 and 1920, while immigration from southeastern Europe, almost non-existent between 1820 and 1860, rose to 44 percent between 1900 and 1920 (Daniels 122). As Roger Daniels reports, in 1860, 84 percent of immigrants were either of British or German origin. In 1890 that number dropped to 63.9 percent, and then in 1920 it shrank further to 27.7 percent (25). In what Daniels calls "the heaviest decade of American immigration, 1901-1910," 1.5 million people came from Britain, Ireland, Germany, and Scandinavian countries, but they were outnumbered by immigrants from Italy, Russia, and Austro-Hungary, which together sent 6.5 million people (188). The new arrivals were quickly labelled "new immigrants" to distinguish them from "old immigrants," who had come from western Europe prior to the 1880s. Although, as June Granatir Alexander notes, many scholars question the justification of this division, claiming that it blurs the real picture of immigration, Alexander considers it helpful because it reflects the contemporary beliefs that had a real impact on the lives of immigrants (13).

Although some anti-immigrant sentiments could be detected prior to the 1890s - for example, the period between the 1830s and the 1850s was characterized by antiCatholicism, directed mainly towards Irish people, and the 1870s witnessed a wave of anti-Asian feelings - only the arrival of eastern and southern Europeans at the turn of the twentieth century aroused considerable hostility towards all immigrants (Daniels 265). This mounting anxiety about the growing immigrant population was reflected in the passage of various legal acts that were supposed to control the process of immigration and adaptation to American society. The Chinese Exclusion Act of 1882 which initially barred Chinese laborers for ten years and was later extended for another decade - was the first step in curbing immigration in general because, as Daniels explains, the exclusion of a certain class of immigrants facilitated further restrictions (272). Other regulations were introduced as well. For example, an 1891 statute limited the entry of mentally ill people and those who could become a liability to the government. A year later, the government opened Ellis Island in New York, where the newly-arrived underwent the admission process, which was supposed to 
determine their eligibility to enter the United States. In 1906, Congress introduced the Nationality Act, which required immigrants who wanted to become citizens of the US to speak English, and in 1911, for the first time in the history of the United States, a special commission was set up with the aim of scrutinizing American immigration. As a result of its work, the Emergency Quota Act was introduced in 1921, limiting the number of migrants from each country. This eventually led to the passage of the Immigration Act in 1924, which changed the law and severely restricted immigration for many decades. An annual limit of 165,000 immigrants was established. As Daniels says, "the 1924 act represented a high-water mark for American nativism" (389). The numbers speak for themselves. In the last four years before the Immigration Act, over 2 million people arrived, despite the quota already being in place, which reduced the number of immigrants by half in comparison to the prewar levels. Ten years later, in the period between 1931 and 1935, immigration dropped to seven hundred thousand (Daniels 289).

14 As a result of heavy immigration at the turn of the twentieth century, American society consisted of many separate nationalities, which triggered efforts to Americanize immigrants. The first attempts of American citizens to facilitate the immigrants' transition can be traced back to the end of the nineteenth century. As Alexander reports, in the late-nineteenth century and the early-twentieth century, various organizations, such as the Daughters of the American Revolution and the Young Men's Christian Association (YMCA), established the first educational programs for immigrants. Some taught them only the English language, while others supplemented English classes with civic training, which was supposed to acquaint the foreign-born with the history of the United States and basic knowledge of the institutions of their new country (Alexander 246-48). While before World War I American society let immigrants decide for themselves how they chose to adapt to their new environment, the escalating conflict in Europe intensified attempts to Americanize them. Alexander describes these shifting moods thus: "In a climate of heightened nationalism, what had been a general indifference about English-language skills or citizenship status gave way to aggressive demands for "Americanization"' (252). She further explains that "Although it was not a well-defined concept, Americanization entailed learning English, becoming a naturalized citizen, embracing 'American' principles, and adopting 'American' standards of living. Being Americanized also meant demonstrating an unqualified allegiance to the United States" (252). Maria Lauret argues that Americanization was not "an organic, inevitable process of immigrant adaptation to the life in the US" as media like to portray it, but "a concerted, top-down, nationwide programme for Americanization of new immigrants" ("Americanization Now and Then" 421-22).

After 1914, the Americanization movement gained impetus. Various organizations including churches, women's clubs, charities, civic groups, and even businesses - took it upon themselves to teach immigrants English and instill in them American values. Henry Ford's "Five Dollar Plan," for instance, was one of the most (in)famous attempts to encourage, or rather force, immigrants to both acquire English and embrace what was believed to be the "American" way of life. Ford Motor Company workers underwent inspections of their private quarters and lives, and if those were deemed to meet "American" standards, then the laborers qualified for a pay rise (Alexander, 253). What is more, in 1914 the company established an English School. ${ }^{9}$ Upon graduation students participated in a ceremony, during which they wore costumes representing 
their native countries, descended into a large "Melting Pot," and came out transformed wearing homogenous clothes and waving American flags ("Melting Pot Ceremony"). In an attempt to unify native and foreign-born Americans, July 4, 1915, known as Americanization Day, was chosen for celebration and filled with parades and gatherings of both immigrants and non-immigrants who listened to speeches, sang patriotic songs, and recited the Pledge of Allegiance. The celebration took place in 150 cities (Mirel 24).

Lauret argues that in its later stages the movement was not only about foreigners, but was also supposed to influence the attitudes of the native-born as well. She explains:

The purpose of the Americanization movement by the 1920 s was ... a far wider one than its initial agenda of fitting the immigrant to American life and industrial work had intended; it was to produce a "one-minded" nation through assimilation of the "foreign element," in the parlance of the day, to the Americanist cause. (435

"Americanization Now and Then." emphasis original)

So the Americanization movement, which had its origins in the settlement movement that was supposed to improve the living conditions of the poor and immigrants, soon became a nation-wide "coercive" program for both native citizens and the foreign-born (Lauret, "Americanization Now and Then" 436). This urge to educate all inhabitants of the United States and to unite them also leaves its trace in some immigrant memoirs.

Thirteen life narratives published between 1900 and 1930 that were classified in Louis Kaplan's A Bibliography of American Autobiographies (1961) as written by immigrants will be categorized here. They can be placed on a continuum where one end is represented by life narratives that were written from the perspective of an immigrant while the other is represented by memoirs which, despite being authored by the foreign-born, do not focus on the experience of migration. In memoirs belonging to the former group, the whole life story is subjected to the immigrant perspective, and the narrative usually takes the form of overcoming initial difficulties and succeeding in a foreign country. This type of life narrative is usually full of comments on the conditions the foreignborn have to endure and sometimes suggestions on how to improve them. The following memoirs, listed alphabetically, are closer to this pole: Mary Antin's The Promised Land (1912); Jacob Cash's What America Means to Me (1925); Constantine Panunzio's The Soul of an Immigrant (1922); M. E. Ravage's An American in the Making (1917); and Edward Steiner's From Alien to Citizen (1914). They are characterized by selfreflexivity and have a plethora of comments on the position of immigrants in American society, and they can be viewed as examples of what Wong calls autobiographies of Americanization - a specific type of immigrant autobiography focused on the transformation of the protagonist into an American citizen (Wong 156). ${ }^{10}$ Most of these autobiographies (Cash would be an exception here) were very popular and have not lost their appeal, as many of them have been in print since their first publication. Stanciu notes that many of them were first published in installments in various magazines, which was a custom of the times and a proof of popularity (11). Antin's work was serialized in The Atlantic Monthly, and Ravage's in Harper's Magazine (Stanciu 11). Some of these authors, like Antin, Panunzio, and Steiner, gave talks on the then-popular lecture circuit. ${ }^{11}$ Many critics point out the educational value of immigrant memoirs, which were frequently recommended in Americanization brochures as facilitating the teaching of English and civics (Pavlenko, "The Making of an American," 42).

19 Another category consists of the in-between memoirs, like Rose Cohen's Out of the Shadow: A Russian Jewish Girlhood on the Lower East Side (1918) or George Linhart's Out of 
the Melting Pot (1923), which recount their authors' struggles in the United States but display little self-reflexivity. Overarching comments on immigration are absent in these books. In-between texts of a different kind include Edward Bok's The Americanization of Edward Bok (1920) and Jacob Riis's The Making of An American (1901). Both texts, as well as their authors, were very popular, and have been customarily, and perhaps erroneously, perceived as classics of immigrant life writing. Riis was a wellknown journalist and social reformer; Bok was the immensely successful editor of one of the most popular women's magazines - Ladies Home Journal. Riis's narrative was serialized in a few periodicals, including The Outlook, The Churchman, and Century Magazine. Bok's The Americanization of Edward Bok received the Pulitzer Prize a year after it was published and held, as Lauret notes, "a prominent place in Americanization programs and civics classes" (12). Both texts were referenced in other memoirs. For example, Panunzio in his foreword remarks that his narrative gives an account of "an average immigrant," explaining that "It is not the life story of a Jacob Riis, an Andrew Carnegie, or an Edward Bok that is told here, but that of an immigrant lad who has been neither too successful nor too unsuccessful" (xi, emphasis original). However, despite their popularity in the immigrant community, neither Bok nor Riis discusses immigration as widely as the previously mentioned authors, and they seem to be more preoccupied with their professional achievements (Riis also writes quite a lot about his personal life, paying special attention to his wife). For that reason, they are classified here as in-between texts. ${ }^{12}$

The other end of the continuum is represented by autobiographies written by immigrants who did not seem to be interested in the experience of migration at all. These books were classified in various bibliographies under the heading immigration, but they either treat the subject of transition to the United States cursorily or not at all, and therefore they are not much different from any other life story. This end of the continuum is represented by Marx Hauberg's Memoirs of Marx D. Hauberg (1923); Adolf Kraus's Reminiscences and Comments: The Immigrant, the Citizen, a Public Office, the Jew (1925); Henry Morgenthau's All in a Life-Time (1921), and Roderick Rombauer's The History of a Life (1903). Morgenthau and Rombauer concentrate on the development of their careers: Morgenthau as a politician, Rombauer as a judge. Hauberg tells the story of his farm life in a very matter-of-fact manner. The subtitle of Kraus's memoir indicates four identities that are important to him, but his identity as an immigrant receives the least attention. The part devoted to it is the shortest: 23 out of 230 -odd pages.

Although these various texts approach migration in very different ways, sometimes ignoring it altogether, narratives from both ends of the continuum are deeply rooted in American culture, as they recycle, or challenge, Franklinian model of the self-made man. However, the present study is predominantly interested in the narratives that explicitly address matters of immigration and assimilation, so the memoirs from the first group. Since it is impossible to discuss all of them here, four were selected for analysis - Mary Antin's The Promised Land, Jacob Cash's What America Means to Me, Constantine Panunzio's The Soul of an Immigrant, and Marcus Eli Ravage's An American in the Making - because each of them represents a slightly different attitude towards the assimilation process. These four texts can be placed on the continuum of their own, where one end is represented by assimilationists and the other by cultural pluralists. The unquestioning acceptance of assimilation is exemplified by Cash's memoir. The Promised Land at first glance is also enthusiastic about assimilation, but a closer 
inspection reveals that Antin is simultaneously aware that this process can take a heavy toll on immigrants. Panunzio's work in effect bridges these two views while Ravage's autobiography defends cultural diversity and is the most explicit in its claim that different ethnic groups can enrich the American way of life.

These books are a curious mix of paying tribute to American values on the one hand, and defending the immigrants who suffered a great deal of prejudice on the other, and as such they served a number of functions. First, they were supposed to give immigration a human face. Writing gave immigrants an opportunity to relate counterstories about experiences of displacement and to dispel the myth of the foreign-born as second-class citizens, especially in times of growing prejudice. The immigrant-authors could also pledge their allegiance to the United States and present themselves as people who did their best to contribute to the greatness of the host country. Secondly, these memoirs served as both consolation and a lesson to fellow immigrants who could find in their pages words of encouragement, the description of familiar experiences, and a recipe for success, which in many instances boiled down to hard work and self-reliance - values important in American culture since the publication of Waldo Emerson's popular essay. Finally, because of their popularity, these texts constituted an important voice in the Americanization debate. While some of them almost blindly supported the process of total assimilation, others questioned it, revealing the great losses for both the native- and foreign-born alike. Whatever stance they adopted, all these authors wrote against the arguments presented by restrictionists, who were determined to curb the influx of newcomers.

The arrival of "new immigrants" coincided with increased interest in Darwin's theory of evolution and Mendel's discoveries of the basic principles of heredity, both of which played roles in debates on immigration. These scientific theories about evolution fueled pseudo-scientific theories regarding the inferiority of certain nations and races. Following historian Audrey Smedley, Mirel explains that:

this new "scientific racism" rested on a series of propositions maintaining that: human beings were members of distinct racial groups; these groups could be ranked hierarchically; physical differences were related to intellectual and moral capabilities; such racial differences were passed on genetically; and environmental factors such as education could not alter inherent dispositions. (37)

24 A number of publications based their arguments on the above assumptions, among them Alfred P. Schultz's Race or Mongrel (1906), Madison Grant's highly influential The Passing of the Great Race (1916), as well as works by prominent sociologists, e.g., Edward A. Ross's The Old World in the New (1914) and Henry Pratt Fairchild's The Melting Pot Mistake (1926). Together, these authors argued that "new immigrants" were of inferior races, and intermingling with them would lead to the inevitable decline of American society. Unlike assimilationists, who had great faith in educating immigrants and instilling in them American values, restrictionists did not believe that education could successfully transform immigrants into desirable citizens.

Assimilationists could count in their ranks some highly respected figures, among them two presidents, Theodore Roosevelt and Woodrow Wilson. Roosevelt was a particularly harsh critic of "hyphenated Americans." The New York Times reported his speech delivered on Columbus Day, 1913 at Carnegie Hall, where he stated:

There is no room in this country for hyphenated Americans. When I refer to hyphenated Americans I do not refer to naturalized Americans. . . . The only absolutely certain way of bringing this nation to ruin ... would be to permit it to 
become a tangle of squabbling nationalities, an intricate knot of GermanAmericans, Irish-Americans, English-Americans, French-Americans, ScandinavianAmericans, or Italian-Americans, each preserving its separate nationality, each at heart feeling more sympathy with Europeans of that nationality than with the other citizens of the American Republic. ("Roosevelt Bars the Hyphenated")

The assimilationists' answer to this "tangle of squabbling nationalities" was education. They strongly believed that by introducing immigrants to American language, culture, manners, and traditions, they would be able to Americanize them and make them an integral part of American society. Assimilationists were not keen on cultivating cultural differences and wanted the new-comers to embrace wholeheartedly the values represented by their new country.

Out of the four memoirs discussed here, the one that is the most enthusiastic about the process of Americanization is What America Means to Me, published in 1925 by Jacob Cash, a Marshall of the City of New York, who was born in Russia. It is also the only autobiography here that was written down by someone other than the protagonist, as Cash told his story to Frank A. Rexford. In the one-page preface, which Cash authored himself, he states his aim: "The purpose of this book is to imbue the residents of our country with an intelligent and friendly attitude toward the government of the United States" (n.pag.). This statement already points to the fact that he wanted to address both the foreign- and native-born, which is consistent with Lauret's argument that in its later stages the Americanization movement was about the creation of an integrated American nation.

Because of his difficult childhood in Czarist Russia, Cash displays no nostalgia for his native country. Being Jewish, he and his family witnessed and experienced persecutions, which only heightens his enthusiasm for his new country. In fact, the first chapter, which in some memoirs includes sentimental reminiscences about the home country, is devoted to the comparison of Russia to the United States. This gives Cash an opportunity to pay tribute to the values he admires in his adopted country values about which America has been boasting since the Declaration of Independence, a fragment of which he even quotes. He writes:

For I came from a land ruled by the "Iron Hand," where refusal to obey the slightest law meant death, to a land of civil and personal liberty; from a land where the pleasant taste of business success might turn to ashes in one's mouth as his good were confiscated, or even burned, with impunity because one was a Jew, to a land which guarantees to everyone his right "to life, liberty, and the pursuit of happiness." (Cash 9)

And he concludes this comparison with an exclamation of loyalty towards his host country: "Small need to ask a man with such a background if he loves America!" (9)

Cash never questions anything American. Even his voyage and the inspection at the border, which other autobiographers remember as a horrific ordeal, is narrated briefly and without a word of complaint. Every utterance seems to be an occasion to remind his readers what a wonderful country America is, and this brief account of Philadelphian streets, which starts as a typical description but ends with elucidating one of the traditional American values - liberty - can serve as a good example: "The little brick houses with their white stone steps set primarily in clean streets seemed the very abodes of a new atmosphere of liberty" (29).

31 The further we progress into Cash's narrative the less personal it becomes. As I have already argued elsewhere, ${ }^{13}$ this book reads like a citizenship manual because it 
includes descriptions of various social and political aspects of his newly-adopted country. Its content brings to mind the agenda of Americanization programs. Cash wants his fellow immigrants to appreciate what America offers them, and therefore he educates them about their new country. Using his personal story, he explains, for example, the process of becoming an American citizen. He recounts how he received his "first papers" three years after landing on the shores of America, and how after two more years, having fulfilled the five-year residence requirement, he applied for full citizenship. Two people had to testify to his moral character, he had to declare his support for the Constitution, and he eventually became "a happy possessor of a certificate of naturalization" (36). This straightforward instruction in the ways of citizenship finishes with him encouraging others to become responsible residents of the United States. He says: "Become active in a political way as soon as possible. While awaiting your final papers, learn the English language. It will help you understand future duties and obligations" (37).

He also explains how different American institutions work. Being a Marshall of New York, he first reveals the responsibilities of various departments of the city government, and then proceeds to describe the workings of the national government, the functioning of Congress, its division into the Senate and the House of Representatives, and the process of creating laws. There are chapters devoted to courts and the Constitution, which is even attached as an appendix at the end of the book. All his explanations are very detailed and written in simple language. The last chapter, tellingly entitled "I love America," is a four-page paean to America and its values mixed with advice on what immigrants should and should not do in their new country. Cash never questions the process of becoming a citizen of a new country. He does not show any nostalgia for either his home country or his former self. He wholeheartedly embraces American ideals and customs, and recommends others to do the same.

Another text which is frequently regarded as a tribute to the process of Americanization is Mary Antin's The Promised Land, which is probably one of the most popular texts examined here. ${ }^{14}$ This memoir, Unlike Cash's, addresses the costs of acculturation, in addition to its enthusiasm about the United States. Antin, who was Jewish and came from the Pale Settlement in Russia, is particularly positive about the education she receives in the United States. In the chapter narrating her entry to the United States she comments: "Education was free. This subject my father had written about repeatedly, as comprising his chief hope for us children, the essence of American opportunity, the treasure that no thief could touch, not even misfortune or poverty" (129). Consequently, the second part of her autobiography, in which she describes her life in America, traces her steps on the educational path. Her words included in the last chapter in a way summarize the goal of her narrative, which is to "trace the footsteps of the young immigrant almost to the college gates" (247). Education is regarded by her not only as a vital step in personal development, but also a wonder of American culture. She comments: "The public schooling has done its best for us foreigners, and for the country, when it has made us into good Americans. I am glad it is mine to tell how the miracle was wrought in one case" (151). Education is in fact important to most of the authors analyzed here, regardless of the views they represent. This should not come as a surprise as public education played a crucial role in the assimilation process. Among various American institutions, Mirel singles out public schools as leading "the effort to Americanize adult immigrants and their children" (Mirel 2). 
Apart from expressing favorable remarks about education, Antin also pays tribute to American values of opportunity, individual freedom, and equality, and self-fashions herself according to the cultural scripts of American society. Hers is a rags-to-riches story, a story of success, of self-reliance and determination that is deeply rooted in American history and can be traced to Benjamin Franklin's Autobiography. Antin, like many male autobiographers from her times who describe the development of their career, follows a Franklinian model of self-improvement. However, as James Craig Holte points out, Antin's focus on acquiring education rather than wealth makes it somewhat different from mainstream male autobiographies (Holte qtd. in Zaborowska 63). Regarded from this perspective, Antin's story may seem like an unhesitating glorification of immigrant assimilation. ${ }^{15}$ However, there are critics who claim that Antin's attitude was to be expected, given the times and the social and cultural background against which she created. Zaborowska, for instance, maintains that "Antin did not have any other choice but to participate in some of the 'paeans' if she wanted a chance to speak for the immigrant cause, if she wanted to see her text in print at all" (60). Linda Brown, in turn, notes, and I have to agree, "Antin subverts her own celebratory narrative to question both the possibility and desirability of full assimilation" by "creating an autobiographical immigrant subject that is far more complex than most critics have acknowledged" (30). However, while Brown reads Antin's assimilation in reference to the formation of racial categories, focusing particularly on her equation of Americanness with whiteness, I want to show that Antin does not wholeheartedly embrace assimilationist claims and points out the costs of the adaptation process.

Although in her introduction Antin declares that the process of assimilation resulted in a new self - for the opening words of her introduction are: "I was born, I have lived, and I have been made over" (xi) - she also admits that it was a painful process. She writes, "All the process of uprooting, transportation, replanting, acclimatization, and development took place in my own soul. I felt the pang, the fear, the wonder. And the joy of it. I can never forget, for I bear the scars" (xiii). On a personal level, she treats her narrative as something that will free her from her past. She explains, "I take the hint from the Ancient Mariner, who told his tale in order to be rid of it" (xiii). But Antin also goes beyond the personal level to examine the outcomes of assimilation. At some point in her memoir she writes that her family wanted her to grow up American and therefore allowed her to follow American ways, which resulted in "the laxity of domestic organization, the inversion of normal relations which makes for friction, and which sometimes ends up in breaking up a family that was formerly united and happy" (185). However, even though she witnesses and participates in this tragedy of readjustment, she considers it an integral "part of the process of Americanization.... It is the cross that the first and second generations must bear, an involuntary sacrifice for the sake of the future generations" (185-86). So, Antin, like Cash, endorses assimilation (her use of the Christian metaphor in the above quote is telling itself, as she grew up in a Jewish family), but unlike him, she also shows the losses immigrants suffer as a result of this process.

The third of the analyzed autobiographies, Constantine Panunzio's The Soul of the Immigrant, published ten years after The Promised Land, in many respects follows in Antin's footsteps, as Panunzio is also clearly in favor of assimilation. However, some of 
his arguments lean towards those expressed by cultural pluralists. His memoir in a way tries to marry these two perspectives.

To realize that The Soul of an Immigrant is another story about Americanization, it suffices to glance at the titles of some of its chapters, for they read: "First Glimpses of the Real America"; "My American Education and Its Meaning"; "I Become Naturalized"; "Stumbling Blocks to Assimilation"; "In an Immigrant Community"; "Still More Obstacles to Assimilation" and "My American Philosophy of Life." From the very beginning, Panunzio, who came from Italy, glorifies the American way of life, and his narrative keeps the promise given in the foreword, namely "to indicate the benefits... [he has] derived from residence in the United States" (xiii). Throughout his text, he uses "my" or "our" country when he talks about America, so he gives a clear indication as to where his loyalties lie. But in case that was not sufficient, he expresses his allegiance to his adopted country even more clearly when he narrates his visit to Plymouth Rock. He says that he often wondered during World War I which country he would support if Italy and America took different sides. Standing upon Plymouth Rock, he realized that "With the least possibility of harm coming to America, it was borne in upon my consciousness what She now meant to me. America in all her fullness was the real life of me" (301). Similarly to Antin, he praises American values of individual freedom, equality, and democracy, and above all, like her, he admires the American educational system. In a letter to his brother he explains for instance that acquiring English allowed him "to know, and in measure to appropriate, the sturdy and wholesome philosophy of the life of the American people" (294). Education is therefore treated as a step towards the discovery of the real America. Thanks to education, immigrants are given access to the best qualities American society has to offer.

Like Antin, Panunzio also deems assimilation a difficult process. However, while Antin considers certain losses on the part of immigrants as a necessary sacrifice from which future generations will benefit, Panunzio is more ambivalent. At a few moments in the narrative he criticizes the fact that one must forget and forgo the heritage, mother tongue, and customs of the native land. For example, he starts the chapter entitled "I become naturalized" by saying that it took him twelve years to pledge allegiance to his adopted country, not because he was not fond of its values or institutions, but because of "those wonderful, inexplicable tendrils which so intertwine themselves around our human hearts in our infancy as to make the country of our birth . . . the one spot on earth around which cluster the sweetest of life's memories" (193). He is critical of the Americanization program and the spirit of compulsion that is perceptible when one arrives in the United States. He comments that the attitude "Either become an American citizen or get out"' is common among many people (194), and he summarizes rather sarcastically the attempts to Americanize the foreign-born: "America thinks that she can make Americans by coercion or by asking the aliens to attend a two-hundredhour course on Americanization" (184). Unlike Cash, who recommends acquiring citizenship as quickly as possible, Panunzio believes that it should be a more organic process. He also points to the limitations of the system, and describes in detail obstacles he encountered while trying to apply for citizenship, some of a legal nature, others connected with the prejudice towards the immigrant community (197-99).

To a greater extent than any other author examined here, Panunzio wishes to influence the way of thinking of native residents of the United States. In this respect, his text is consistent with Lauret's claim that in its later stages Americanization was about 
education of both the native- and the foreign-born. Panunzio frequently addresses his American audience and asks them for understanding. The chapter entitled "My American Big Brother" describes an anonymous person who helped Panunzio to adjust to the American way of life by showing him kindness and constant support. Panunzio believes that "one ounce of this kind of treatment will do more to make Americans than a million pounds of the Americanization cure" (223). He therefore addresses all Americans and asks them for sympathy for the immigrant cause, thus suggesting that every single individual has to assume responsibility for the creation of a united country. Not only immigrants but also natives have to change their attitudes and adapt to the new circumstances.

Panunzio is fully convinced that immigrants should not divest themselves of their ideals and traditions, for "every immigrant brings something with him from his native land which is worthy of perpetuation, and which, if properly encouraged and developed, may become a contribution to our national life" (188-89). He also elaborates on the losses he suffered due to migration, and these are moral, spiritual, as well as physical. He lost his simplicity, the respect for law and order instilled in him in childhood, the meticulous attitude to work acquired in Italy, and, on the top of it all, he also lost his health (184-87). All these represent the potential he could have contributed to his adopted country. He believes that assimilation will be facilitated if migrants are allowed to contribute the best their nations have to offer.

41 In this respect, he follows cultural pluralists who were critical of a melting-pot theory and strongly supported the idea that each nation should maintain its own distinct identity. One of the people who challenged the growing antagonism towards immigrants and spoke against the total assimilation of diverse populations was the critic and intellectual Randolph S. Bourne, who presented his progressive beliefs in an essay entitled "Trans-National America," which originally appeared in The Atlantic in 1916. Bourne believes that embracing differences between nations can strengthen American society. He argues that the ideal of a melting pot is at odds with democratic standards because it does not give all the governed an equal say in how they want to participate in the life of the nation. He reminds his readers that all Americans are in fact either foreign-born or the descendants of the foreign-born, and that from the early times people have come to America to "escape from the stifling air and chaos of the old world" (Bourne 1). He warns that the "Anglo-Saxon element is guilty of just what every dominant race is guilty of in every European country: the imposition of its own culture upon the minority people" (1). Although he suggests that not all nations are equal, thus perpetuating some racist notions, he believes that this inferiority is not inherent, racial-based, but rather cultural, and it can be addressed with the right education. His statement - "Let us speak not of inferior races, but of inferior civilizations" (1) - was highly forward-thinking in light of opinions expressed by many people, restrictionists included, at the turn of the twentieth century. Bourne believes that the individuality of each nation should be treasured, and America should become, and in many ways already is, "a federation of cultures" (1). Seeing the distinctiveness of the United States in its acceptance of diversity, he explains that immigrants should not be regarded as "masses of aliens, waiting to be 'assimilated,' but as "threads of living and potent cultures, blindly striving to weave themselves into a novel international nation, the first the world has seen" (1). 
While Panunzio entertained some ideas that might resonate with those expressed by cultural pluralists, his pleas were rather cautious, and his criticism rather meek. The last author examined here was far bolder in his demands and opinions. The difference between Panunzio and Ravage towards Americanization is quite well illustrated by the way in which they describe the change of immigrants' names. It was a common practice among immigrants to give up their birth name and adopt a more American-sounding name, and this transformation, for many a serious blow to their identity, is narrated in many autobiographies of the time. Panunzio takes a humorous stance towards this renaming, recounting it thus:

The name which George Annis gave me ... far excelled that for its true American origin; in its very atmosphere it was American, and fairly smelled of Americanism. For a period of some three months I was known as "Mr. Beefsteak." When I discovered its true significance, I naturally objected to passing for Italian tenderloin. Then George gave me a second name, Frank Nardi, which stayed with me until I entered school and was able to assume my own name again. (107)

Ravage is far more critical of this practice. He writes:

With every day that passed I became more and more overwhelmed at the degeneration of my fellow-countrymen in this new home of theirs. Even their names had become emasculated and devoid of either a character or meaning. Mordecai - a name full of romantic association - had been changed to the insipid monosyllable Max. Rebecca - mother of the race - was in America Becky.... Whole battalions were called Joe; the Harrys alone could have repopulated Vaslui; and of Morrises there was no end. With the women-folks matters went even worse. It did not seem to matter at all what one had been called at home. The first step toward Americanization was to fall into one or the other of the two great tribes of Rosies and Annies. (78).

He then explains that he quickly discovered that the demand for transformation went beyond these external markers of identity.

Ravage is critical of how Americans imagine Americanization. He comments: "These kindly ladies and gentlemen appear to assume that the trick of turning American is some kind of an affair of a rubber stamp and an oath of allegiance and bath-tubs" (137). He writes against Roosevelt's and Wilson's criticism of hyphenated Americans, explaining that for him, "the adoptive American has always been and will always remain a composite American" (138). Similarly to cultural pluralists, he strongly believes that "the alien has as much to teach as to learn, that his readjustment is inevitably a matter of give and take" (138). He therefore supports the idea of assimilation as a process of cultural exchange rather than coercion and conformity on the part of immigrants. He says:

the alien who comes here from Europe is not the raw material that Americans suppose him to be. He is not a blank sheet to be written on as you see fit .... Quite the contrary. He brings with him a deep-rooted tradition, a system of culture and tastes and habits - a point of view which is as ancient as his national experience and which has been engendered in him by his race and his environment. (60-61)

He also warns Americans that blind demand for Americanization might work against them and their intention of forming a united nation. He is critical of the transformation the migrants have to undergo in the effort to become Americans because, as he explains, "Cut adrift suddenly from their ancient moorings" immigrants often find themselves "in a sort of moral void" (79). He further explains that certain desirable attitudes or behaviors such as "good manners and good conduct, reverence and 
religion, had all gone by the board" simply because these things were not considered American (79). His description of disintegrated families is very similar to that presented by Antin. He describes how migrants change and how family relations are strained because of the growing gap between generations. However, despite being undoubtedly the most critical about Americanization of all the authors examined here, he also finishes his memoir with an upbeat exclamation of how he realized that he "was not a man without a country. [He] was an American" (266).

To sum up, answering Wong's call for a more scrupulous use of the term immigrant autobiography, this paper has demonstrated that immigrant status does not determine the content of life narratives. It has become evident that some immigrant authors do not see their life through lenses of immigration, and frequently recount their life stories ignoring the experience of transition to another country altogether. This raises at least two interesting questions: one about nomenclature-which texts should be called "immigrant autobiography"?-the other about alternative common denominators in these life narratives.

In answer to the first one, I have suggested that memoirs composed by immigrants should be placed on a continuum, where one end is represented by books that have immigration dilemmas at their heart while the other is represented by rather standard autobiographies in which immigrant status is irrelevant. Autobiographies from the first three decades of the twentieth century that have been given most academic attention are the ones that explore the immigrant question. They have been named by Wong as Americanization autobiographies, and perhaps this is a more appropriate term for them. Therefore, we can regard Americanization autobiography as a variety of immigrant autobiography, which, in turn, is a subgenre of ethnic autobiography. The continuum may also help future scholars to rethink the position of certain works which have been often regarded as classics of immigrant literature. For instance, close reading of Bok's or Riis's memoirs (particularly the former) reveals that these authors gave more space to recounting their self-development than to discussing an immigrant question. Yet, both are considered classic immigrant texts. Perhaps it would be worthwhile to examine how market forces aided their reputation in this respect.

As for the answer to the second question, following Wong, I believe that criteria other than immigrant status might prove equally, if not more, productive in the analysis of immigrant memoirs. Ethnicity in particular may deserve special attention, especially when we take into account the fact that out of thirteen autobiographies catalogued here, seven (Antin, Cash, Cohen, Kraus, Morgenthau, Ravage and Steiner) were composed by Jewish authors. This is only mildly surprising as the Jewish community has always insisted on educating their members, and as a result had higher literacy rates than other ethnic groups. Focus on exclusively Jewish immigrant memoirs might result in producing some interesting findings, especially in the light of their authors' diverse attitudes towards their origin and religion (e.g., Antin shed her Jewishness; Steiner converted to Christianity; Kraus and Morgenthau defended their community and reported on the increasingly difficult situation of Jews in Europe).

The core of this article was devoted to demonstrating that many of the now classic texts on Americanization took an active part in the national debate about immigration, a debate that was triggered by waves of "new immigrants" arriving in droves from southern and eastern Europe, and veered between two popular positions: assimilation vs. cultural pluralism. Some memoirs wholeheartedly embraced the idea of America as 
a melting pot and urged their fellow-citizens to adapt to American ways; others, more in line with cultural pluralists, were more ambivalent about the Americanization process, and tried to present immigrants as individuals who could contribute something of value to their new country. Whatever perspective they assumed, they wrote against flourishing restrictionist arguments which called for a reduction in the numbers of immigrants and a national uniformity.

51 Finally, this essay, perhaps more implicitly than explicitly, calls for more attention to immigrant life narratives in the context of early-twentieth-century American literature. The first three decades of twentieth century American literature are commonly associated with either modernism and lost generation writers (such as Ernest Hemingway, Gertrude Stein, or Francis Scott Fitzgerald), modernist poets (among them Ezra Pound, H.D., William Carlos Williams), or, alternatively, with two renaissance movements - the Southern Renaissance, which explored the burden of the racial past and conservative culture of the South, and the Harlem Renaissance, which revived Afro-American art and literature. If immigrant literature is given any attention, it is usually investigated in the fictional output of such writers as Upton Sinclair (The Jungle), Anzia Yezierska (Hungry Hearts, Salome of the Tenements, Bread Winners), or Willa Cather (O Pioneers, My Ántonia) - all of whom depicted struggles of immigrants and costs of acculturation. Immigrant memoirs from the early twentieth century are rarely treated as a body of works, and more attention is given to individual autobiographies, some of which - Antin, Bok, Panunzio, Ravage, Riis - are examined more often than others. I believe that investigating these texts together can not only help us tease out differences and similarities between them but also, perhaps more importantly, contribute to a more complete version of American literary and cultural history in a period that was marked by an unprecedented influx of immigrants. The voices of millions of people who arrived then in the United States should be given more visibility because in times of growing concerns about American identity, personal immigrant life stories revealed the concerns and dreams of their authors, gave access to first-hand accounts of their transition and assimilation, and provided valuable insights into contemporary national debates.

\section{BIBLIOGRAPHY}

Alexander, June Granatir. Daily Life in Immigrant America. 1870-1920: How the Second Great Wave of Immigrants Made Their Way in America. Chicago: Ivan R. Dee, 2009.

Antin, Mary. The Promised Land. 1912. Mineola: Dover Publications, 2012.

Bourne, Randolph. "Trans-National America.” The Atlantic, July 1916. Accessed 1 October 2019. www.theatlantic.com/magazine/archive/1916/07/trans-national-america/304838/.

Boelhower, William. Immigrant Autobiography in the United States: Four Versions of the Italian Self. Verona: Essedue Edizioni, 1982. 
---. "The Making of Ethnic Autobiography in the United States." American Autobiography: Retrospect and Prospect, edited by Paul John Eakin, Madison: U of Wisconsin P, 1991, pp. 123-41.

Bjorklund, Diane. Interpreting the Self: Two Hundred Years of American Autobiography. Chicago: U of Chicago P, 1998.

Brown, Linda. The Literature of Immigration and Racial Formation: Becoming White, Becoming Other, Becoming American in the Late Progressive Era. New York: Routledge, 2004.

Cash, Jacob. What America Means to Me. New York: United States Patriotic Society, 1925.

Daniels, Rogers. Coming to America: A History of Immigration and Ethnicity in American Life. $2^{\text {nd }}$ ed., New York: Harper Collins, 2002.

Kaplan, Louis. A Bibliography of American Autobiographies. Madison: U of Wisconsin P, 1961.

Lauret, Maria. “Americanization Now and Then: The 'Nation of Immigrants' in the Early Twentieth and Twenty-First Centuries." Journal of American Studies, vol. 50, no. 2, 2016, pp. 419-447.

---. “When Is an Immigrant's Autobiography Not an Immigrant Autobiography? The Americanization of Edward Bok." Melus, vol. 38, no. 3, 2013, pp. 7-24.

"Melting Pot Ceremony at Ford English School, July 4, 1917." The Henry Ford. Accessed 15 November 2019. www.thehenryford.org/collections-and-research/digital-collections/artifact/ $254569 /$.

Mirel, Jeffrey E. Patriotic Pluralism: Americanization Education and European Immigrants. Cambridge: Harvard UP, 2010.

Panunzio, Constantine. The Soul of an Immigrant. New York: The Macmillan Company, 1922.

Pavlenko, Aneta. “'Ask Each Pupil About Her Methods of Cleaning': Ideologies of Language and Gender in Americanisation Instruction (1900-1924)." International Journal of Bilingual Education and Bilingualism, vol. 8, no. 4, 2005, pp. 275-297.

---. "The Making of an American: Negotiation of Identities at the Turn of the Twentieth Century." Negotiations of Identities in Multilingual Contexts, edited by A. Pavlenko and A. Blackledge, Clevedon: Multilingual Matters, 2004, pp. 34-67.

Ravage, Marcus Eli. An American in the Making: The Life Story of an Immigrant. New York: Harper and Brothers, 1917.

"Roosevelt Bars the Hyphenated." The New York Times, 13 October 1915, p. 1. Accessed 1 February 2019. timesmachine.nytimes.com/timesmachine/1915/10/13/105042745.pdf.

Stanciu, Cristina. "Marcus E. Ravage's An American in the Making, Americanization, and the New Immigrant Representation.” Melus, vol. 40, no. 2, 2015, pp. 5-29.

Tuerk, Richard. "At Home in the Land of Columbus: Americanization in European-American Immigrant Autobiography." Multicultural Autobiography: American Lives, edited by J. R. Payne, Knoxville: The U of Tennessee P, 1992, pp. 114-138.

Wong, Sau-ling Cynthia. "Immigrant Autobiography: Some Questions of Definitions and Approach." American Autobiography: Retrospect and Prospect, edited by Paul John Eakin, Madison: U of Wisconsin P, 1991, pp. 142-170.

Zaborowska, Magdalena. How We Found America: Reading Gender Through East European Immigrant Narratives. Chapell Hill: U of North Carolina P, 1995. 


\section{NOTES}

1. J. E. Mirel, in his book Patriotic Pluralism: Americanization Education and European Immigrants, differentiates between assimilationists and amalgamationists, saying that the former wanted immigrants to divest of their former identity and national traits while the latter believed that the mixing of various groups would produce a new nation $(25 ; 33)$. However, he also admits that in many ways the position represented by amalgamationists veers between cultural pluralism and ideas represented by assimilationists (see pp. 33-35), and that educators were also divided into two camps (those supporting assimilation and those supporting diversity) (see p. 49), so in order not to unnecessarily complicate our argument, I follow other critics, like Linda Brown, who distinguish the three main positions listed in the introductory paragraph.

2. J. E. Mirel explains that the metaphor of a melting pot was used by both assimilationists and amalgamationists, "either as an instrument of assimilation or as the creator of a new, composite American race" (48-49).

3. Once the authors of memoirs became celebrities, like Mary Antin, for example, they could influence public opinion in other fora. Zaborowska notes that apart from publishing her classic memoir The Promised Land in 1912 and a defence of American democracy in They Who Knock at Our Gates two years later, Antin gave "lectures on immigrant, Jewish, and feminist issues; and speeches for the National Americanization Committee, the National Security League, and the U.S government's committee on public information" (53). Her memoir therefore created new opportunities for speaking on behalf of the immigrant community.

Throughout this essay I use autobiography and memoir interchangeably, although I believe that 'memoir' is a more appropriate term for some of the texts that are analyzed here because of their clear focus on the experience of migration. For a detailed discussion of the memoir/ autobiography debate see: Rak, "Are Memoirs Autobiographies: A consideration of Genre and Public Identity," Genre 2004, xxxvi, pp. 305-326; Jarczok, "Language, narrative, self, and memory in two language memoirs: Eva Hoffman's Lost in Translation and Ilan Stavans's On Borrowed Words," Bibliotekarz Podlaski, (2) 2020, pp. 81-109.

4. I am far from claiming that life genres are devoid of literary values. Nonetheless, reading through various immigrant memoirs, one can quickly notice that some are more literary than others. There are memoirs which recount lives in a very straightforward, literal, chronological, and simple manner while others make use of various literary devices, such as foreshadowing, imagery, irony, etc. The language used in the latter is noticeably more complex and elaborate.

5. Out of the one hundred and seventy texts written by immigrants between 1800 and 1979 which Diane Bjorklund lists in her study Interpreting the Self: Two Hundred Years of American Autobiography (1998), only eleven were published in the nineteenth century. It is therefore clearly a genre that belongs to the twentieth century.

6. William Boelhower, in an article "The Making of Ethnic Autobiography in the United States" (1991), uses an alternative term for immigrant autobiography - ethnic autobiography, and throughout his essay he uses these two terms interchangeably. Also, his earlier classic Immigrant Autobiography in the United States: Four Versions of the Italian Self (1982), which seems to be, as its title suggests, devoted solely to immigrant life narratives, again collapses immigrant autobiography into ethnic autobiography as one of four authors that he discusses, namely Jerre Mangione, was born in United States to Italian parents. Revising literature on the subject of immigrant autobiography up to 1991, Sau-ling CynthiaWong also notices that it is a common practice "to subsume immigrant autobiography under ethnic autobiography" (143). It must still be the case as, to my knowledge, there are no studies that would focus exclusively on immigrant memoirs (only individual texts are analyzed). In my understanding, ethnic autobiography is a broader category that encompasses immigrant autobiography. In other words, immigrant autobiography is a subgenre of ethnic autobiography. 
7. For a detailed critique of Boelhower's study see Sau-ling Cynthia Wong's article "Immigrant Autobiography: Some Questions of Definition and Approach."

8. Wong criticizes Boelhower for conflating writings of immigrants and those who were born to immigrant parents (like Mangione) and who did not experience migration directly.

9. Quoting historians Allan Nevins and Frank Hill, Mirel notes that "the Ford program appears to have been far less successful than its contemporary publicists or later historians maintained," because out of 14,000 students enrolled in the classes only 1,500 graduated with a diploma that certified the completion of a 72-hour course (89).

10. In her article "The making of Ethnic Autobiography in the United States" Wong criticizes Boelhower for conflating immigrant autobiography with autobiography of Americanization.

11. See Stanciu, ibid., p. 11 and A. Pavlenko, 'The Making of an American': Negotiation of Identities at the Turn of the Twentieth Century [in] Negotiations of Identities in Multilingual Contexts, eds. A. Pavlenko and A. Blackledge, Clevedon, 2004, Multiligual Matters, Ltd. p. 42.

12. Maria Lauret expresses her surprise that Bok's text is frequently regarded as a classic of immigration literature because, as she puts it, "The autobiography's interest lies neither in its literary merit nor in what it has to say about the author's immigrant experience" (7). She believes that Bok's text was instead intended to educate the native-born (8). M. Lauret, "When Is an Immigrant's Autobiography Not an Immigrant Autobiography? The Americanization of Edward Bok." Melus, 38 (3), 2013, p. 7; 8.

13. Jarczok, Anita. "Reminiscing the Past, Pointing to the Future: Immigrant Memoirs from the Early-Twentieth-Century United States," Świat i Słowo, 34, 2020 (2).

14. See, for instance, Mirel p. 27.

15. Being a woman, Antin was culturally predisposed to support assimilation because Americanizers often targeted immigrant women as significant agents of socialization of their families. In her article “"Ask Each Pupil About Her Methods of Cleaning': Ideologies of Language and Gender in Americanisation Instruction (1900 - 1924)," Aneta Pavlenko, for instance, demonstrates that English classes for women had the "hidden curriculum" "which aimed to impose on the women a particular model of middle-class domesticity" (287). For more on gender and Americanization see also John F. McClymer "Gender and the 'American Way of Life': Women in the Americanization Movement."Journal of American Ethnic History, Spring 1991.

\section{ABSTRACTS}

This article analyzes four immigrant memoirs - Mary Antin's The Promised Land (1912); Jacob Cash's What America Means to Me (1925); Constantine Panunzio's The Soul of an Immigrant (1922), and M. E. Ravage's An American in the Making (1917) - in the light of their contribution to the nationwide debate over immigration that took place against the background of heightened antagonism towards the immigrant community at the beginning of the twentieth century in the United States. It argues that these life narratives represent diverse perspectives on the Americanization process: two of them - Cash's and Antin's - seem to endorse the assimilationist point of view, while the other two - Panunzio's and Ravage's - lean more towards arguments voiced by cultural pluralists. All four texts try to refute restrictionists' claims based on pseudoscientific racial theories. This article also suggests a way of classifying autobiographies authored by European immigrants at the turn of the twentieth century. 
INDEX

Keywords: immigrant autobiography, immigration, Americanization, Hawai'i, assimilation, cultural pluralism, restrictionism, Mary Antin, Constantine Panunzio, M. E. Ravage, Jacob Cash.

\section{AUTHOR}

\section{ANITA JARCZOK}

Anita Jarczok is currently working on the project devoted to memory and migrant memoirs, and her research has been supported by the grant she received from the National Science Centre (NCN) as part of "Miniatura" funding scheme (no. 2017/01/X/HS2/00517). 